\title{
Rancang Bangun Deteksi Air Hujan dengan Report Via SMS Berbasis Arduino Uno
}

\author{
Jaenal Arifin $^{1}$, Danny Kurnianto ${ }^{2}$, Eto Salam ${ }^{3}$ \\ Program Studi S1 Teknik Elektro ${ }^{1}$, Program Studi D3 Teknik Telekomunikasi ${ }^{2,3}$ \\ Fakultas Telekomunikasi \& Elektro, Institut Teknologi Telkom Purwokerto \\ Jl. D.I Panjaitan No.128 Purwokerto 53147 Telp 0281-641629 \\ Jaetoga@ittelkom-pwt.ac.id ${ }^{1}$ \\ dannykurnianto@ittelkom-pwt.ac.id \\ d312014@akatelsp.ac.id ${ }^{3}$
}

Intisari---Sistem kendali secara otomatis di bidang ilmu pengetahuan dan teknologi belakangan ini berkembang dengan pesat sehingga menghasilkan inovasi baru. Menjemur pakaian merupakan salah satu kegiatan yang sering dilakukan didalam kehidupan. Menjemur pakaian sering kali ditinggal pergi, sehingga tidak sempat lagi untuk mengangkat jemuran pada waktu hujan turun. Ini bisa menjadi masalah, dalam penelitian ini mengusulkan solusi berupa perangkat yang dapat memberi tahu kondisi cuaca hujan. Perangkat deteksi air hujan ini dibuat dengan menggunakan papan konduktor PCB sebagai sensor air hujan, motor DC berfungsi menutup dan membuka tempat jemuran, mikrokontroler arduino uno digunakan sebagai pengendali utama perangkat ini dan modem wavecome digunakan untuk mengirim sms berupa pemberitahuan ketika hujan turun. Perangkat deteksi air hujan ini dapat bekerja sesuai dengan apa yang diharapkan. Pengujian perangkat ini meliputi pengujian catu daya, sensor air hujan, pengujian driver motor L293D dan pengiriman pesan sebagai notifikasi sms hujan dan tidak hujan.

Kata kunci--- Sensor Air Hujan, Arduino UNO, Modem Wavecom, Motor DC

Abstract---Automatic control systems in science and technology have recently been developed rapidly in order to produce new innovations. Drying clothes is one of daily life activities. Drying clothes is usually left open in the field using clothesline, so that there is not enough suitable time to carry the clothes when rain fall from the sky. This can be a problem, so that in this study, we propose a device that can inform the condition during the rain. This rainwater detection device is created by using a PCB conductor board as a rainwater sensor, the DC motor whose function is to close and open the clothesline, the Arduino Uno microcontroller which is used as the main controller of this device and the wavecome modem that is used to send SMS notifications when the rain come. This rainwater detection device can work as expected. Testing on this device consists of testing the power supply, testing the rainwater sensors, testing the L293D motor driver and testing sending messages as a notification whether there is rain or not. Keywords---Rain Water Sensor, Arduino UNO, Wavecom Modem, DC Motor. 


\section{PENDAHULUAN}

Perkembangan teknologi begitu pesat menjadikan semuanya dapat dicarikan solusi dari suatu masalah yang ada dilingkungan sekitar kita. Masalah yang ada disekitar kita seperti ketika menjemur pakaian dan tiba-tiba turun hujan atau pada saat jemuran pakaian ditinggal, setelah kembali ke rumah pakaian sudah basah karena turun hujan. Dari masalah tersebut penulis mencoba mencari solusi dengan membuat perangkat yang dapat memberikan informasi turunnya air hujan. Membuat perangkat deteksi air hujan dengan report via sms berbasis arduino uno. Penelitian ini menggunakan sensor air hujan, Arduino Uno, motor DC, modem wavecom dan telephone seluler.

Pada penelitian lain terkait sistem pengendali dan pengamanan pintu yang memanfaatkan motor DC sebagai penggerak pintu [1]. Penelitiannya memberikan manfaat untuk mengendalikan pintu secara jarak jauh dan dapat dikontrol menjadi lebih mudah dan efisien dengan memanfaatkan teknologi yaitu media kartu sebagai identifikasi dan telephone seluler. Dalam penelitian lain terkait monitoring deteksi hujan [2] mengutarakan bahwa dalam mendeteksi air hujan dapat dimonitoring secara real time. Dalam penelitiannya mochammad haldi [3] mencoba pengaplikasian sensor hujan dan LDR untuk lampu mobil otomatis berbasis Arduino Uno.

Penelitian sebelumnya telah dilakukan dengan memanfaatkan sensor hujan [4]. Dalam penelitiannya mengutarakan bahwa penelitian dengan judul sistem kontrol atap otomatis tempat penjemuran berbasis mikrokontroler Arduino uno dan node sensor dapat dilakukan. Dari rancang bangun hardware seperti sensor DHT22, sensor hujan, sensor LDR, mikrokontroler, motor servo dan kipas angin dapat bekerja sesuai dengan apa yang telah diharapkan. Manfaat dalam penelitian tersebut mengamankan jemuran pakaian dengan sistem kontrol secara otomatis dengan memanfaatkan mikrokontroler Arduino Uno sebagai pengendalinya.

\section{DASAR TEORI}

\section{A. Sensor Air Hujan}

Sensor ini dibuat menggunakan papan PCB sebagai detektor air hujan. Detektor air hujan ini merupakan jenis komponen yang akan akif jika terkena air [5].

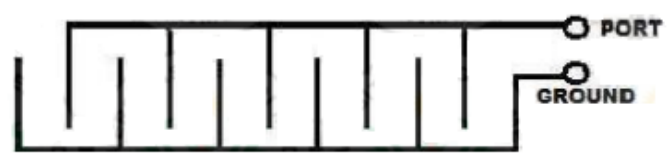

Gbr 1. Desain sensor air hujan

Sensor ini dapat digunakan untuk berbagai kondisi cuaca, tegangan operasi sensor ini dari $3.3 \mathrm{~V}-5 \mathrm{~V}$ dan tegangan yang dipakai adalah $5 \mathrm{~V}$, ouput dari sensor air ini dapat dihubungkan ke analog input dari arduino. Prinsip kerja dari sensor ini jika detektor atau papan PCB terkena air hujan maka jalur antara port dan ground akan terhubung. sehingga nilai tegangan di port akan bernilai nol karena terhubung langsung dengan ground [5].

\section{B. Arduino Uno R3}

Arduino UNO R3 merupakan sebuah board mikrokontroler yang didasarkan pada ATmega328 (datasheet). Arduino UNO mempunyai 14 pin digital input/output (6 di antaranya dapat digunakan sebagai output PWM), 6 input analog, sebuah osilator Kristal $16 \mathrm{MHz}$, sebuah koneksi USB, sebuah power jack, sebuah ICSP header, dan sebuat tombol reset [6].

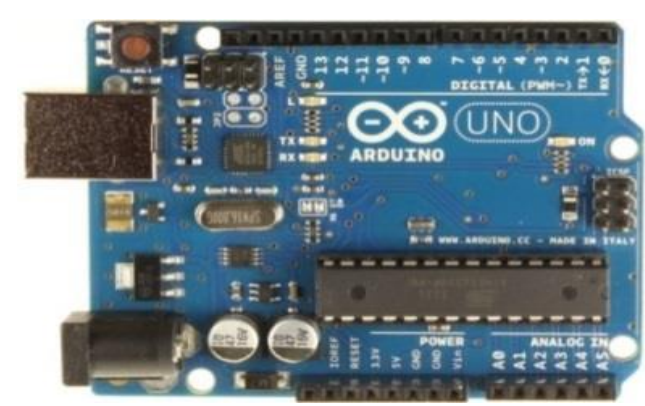

Gbr 2. Board Arduino Uno R3[7]

Arduino Uno berbeda dari semua board Arduino sebelumnya, Arduino UNO tidak menggunakan chip driver FTDI USB-toserial. Sebaliknya, fitur-fitur Atmega16U2 (Atmega8U2 sampai ke versi R2) diprogram sebagai sebuah pengubah USB 
ke serial [8].

Tabel 1 Spesifikasi Arduino UNO R3.

\begin{tabular}{|l|c|}
\hline \multicolumn{1}{|c|}{ Parameter } & Spesifikasi \\
\hline Mikrokontroler & ATmega328 \\
\hline Tegangan Operasional & $5 \mathrm{~V}$ \\
\hline $\begin{array}{l}\text { Tegangan input yang } \\
\text { disarankan }\end{array}$ & $7-12 \mathrm{~V}$ \\
\hline Batas tegangan input & $6-20 \mathrm{~V}$ \\
\hline Jumlah pin I/O digital & 14 (6 di antaranya PWM) \\
\hline Jumlah pin analog & 6 \\
\hline Arus DC tiap pin I/O & $40 \mathrm{~mA}$ \\
\hline Arus DC pin 3.3V & $50 \mathrm{~mA}$ \\
\hline Memori Flash & $32 \mathrm{~KB}(\mathrm{ATmega328})$ \\
\hline SRAM & $2 \mathrm{~KB}(\mathrm{ATmega328})$ \\
\hline EEPROM & $1 \mathrm{~KB}(\mathrm{ATmega328})$ \\
\hline Clock Speed & $16 \mathrm{MHz}$ \\
\hline
\end{tabular}

\section{IC LM 393}

IC LM393 merupakan IC yang berfungsi untuk membandingkan dua macam tegangan yang terdapat pada kedua inputnya. Dalam 1 (satu) kemasannya mempunyai dua buah komparator didalamnya .

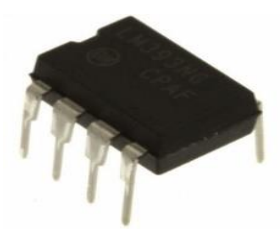

Gbr 3. Bentuk fisik IC LM393 [9]

IC komparator LM 393 memiliki fitur-fitur sebagai berikut:

a. Dapat bekerja dengan single supply $2 \mathrm{~V}$ sampai 36V.

b. Dapat bekerja dengan tegangan input $3 \mathrm{~V}$ sampai $+36 \mathrm{~V}$.

c. Dapat bekerja dengan segala macam bentuk gelombang logic

d. Dapat membandingkan tegangan yang mendekati ground.

LM393 memiliki 2 buah input dan sebuah output berikut skemanya :

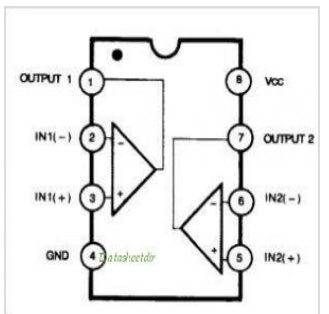

Gbr 4. Pin IC LM393 [9]

IC LM393 memiliki dua buah komparator atau pembanding yang akurat dan tidak saling berhubungan yaitu inverting (-) dan non-inverting $(+)$. Komparator memiliki output yaitu low atau high. Cara kerja komparator memiliki ketentuan sebagai berikut :

1. Inverting : $\mathrm{V}->\mathrm{V}+=$ Low $\mathrm{V}-\leq \mathrm{V}+=$ High

2. Non-inverting $: \mathrm{V}+>\mathrm{V}-=$ High $\mathrm{V}+\leq \mathrm{V}-=$ Low

\section{Motor DC}

Kumparan medan pada motor DC disebut stator dan kumparan jangkar disebut rotor, jika terjadi putaran pada kumparan jangkar dalam pada medan magnet, maka akan timbul tegangan yang akan berubahubah arah pada setiap setengah putaran, sehingga merupakan tegangan bolak-balik prinsip kerja dari arus searah adalah membalik phasa tegangan dari gelombang yang mempunyai nilai positif dengan menggunakan komutator.

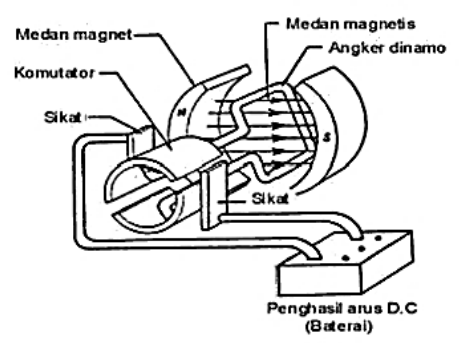

Gbr 5. Motor DC [10]

Dengan demikian arus yang berbalik arah dengan kumparan jangkar yang berputar dalam medan magnet. Bentuk motor paling sederhana memiliki kumparan satu lilitan yang bisa berputar bebas diantara kutubkutub magnet permanen. Prinsip Arah Putaran Motor. Prinsip motor dc : aliran arus di dalam penghantar yang berada di dalam pengaruh medan magnet akan menghasilkan gerakan. Besarnya gaya pada penghantar akan bertambah besar jika arus yang melalui penghantar bertambah besar.

\section{E. IC L293D}

Untuk menggerakan motor DC diperlukan sebuah penggerak berupa IC L293D, IC L293D merupakan IC yang didesain khusus sebagai driver motor DC dan 
dapat dikendalikan dengan rangkaian TTL maupun mikrokontroler. Motor DC yang dikontrol dengan driver IC L293D dapat dihubungkan ke ground maupun ke sumber tegangan positif karena di dalam driver L293D sistem driver yang digunakan adalah totem pool. Dalam 1 unit chip IC L293D terdiri dari 4 buah driver motor DC yang berdiri sendiri sendiri dengan kemampuan mengalirkan arus 1 Ampere tiap drivernya. Sehingga dapat digunakan untuk membuat driver H-bridge untuk 2 buah motor DC. Berikut pin IC L293D :

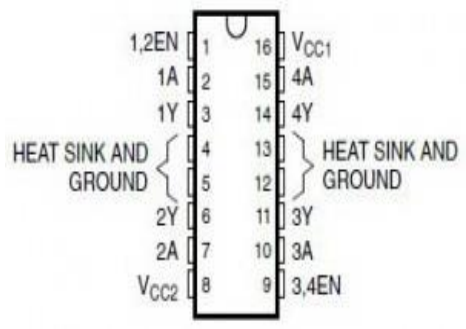

Gbr 6. Pin IC L293D [11]

Berikut fungsi dari masing- masing pin :

- Pin EN (Enable, EN1.2, EN3.4) berfungsi untuk mengijinkan driver menerima perintah untuk menggerakan motor DC.

- $\quad$ Pin In (Input, 1A, 2A, 3A, 4A) adalah pin input sinyal kendali motor DC

- Pin Out (Output, 1Y, 2Y, 3Y, 4Y) adalah jalur output masing-masing driver yang dihubungkan ke motor DC

- Pin VCC (VCC1, VCC2) adalah jalur input tegangan sumber driver motor DC, dimana VCC1 adalah jalur input sumber tegangan rangkaian kontrol dirver dan VCC2 adalah jalur input sumber tegangan untuk motor DC yang dikendalikan.

- Pin GND (Ground) merupakan jalur yang harus dihubungkan ke ground, pin GND ini ada 4 buah yang berdekatan dan dapat dihubungkan ke sebuah pendingin kecil.

Pada dasarnya beberapa aplikasi yang menggunakan motor DC harus dapat mengatur kecepatan dan arah putar dari motor DC itu sendiri. Untuk dapat melakukan pengaturan kecepatan motor DC dapat menggunakan metode PWM (Pulse Width Modulation) sedangkan untuk mengatur arah putarannya dapat menggunakan rangkaian H-bridge yang tersusun dari 4 buah transistor. Tetapi dipasaran telah disediakan ICL293D sebagai driver motor DC yang dapat mengatur arah putar. 2.5 Modem GSM Wavecom Modem GSM Wavecom perangkat yang dapat mengirimkan informasi berupa sms (Short Message Service) secara broadcast atau menyebar secara bersamaan dengan dukungan provider operator GSM (Global System for Mobile communication)

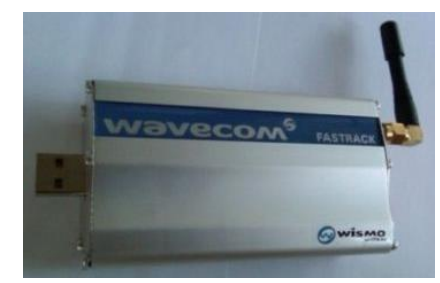

Gbr 7. Modem GSM Wavecom [12]

Modem GSM wavecom sering digunakan untuk perangkat pendukung pada sebuah sistem yang menggunakan report SMS atau dial sebagai outputnya. Modem wavecom bekerja dengan menerima data dari mikrokontroller yang berupa perintah untuk dial atau SMS melalui port RS232 yang selanjutnya oleh modem akan dikirimkan ke nomor handphone tujuan.

Port data pada modem wavecom ada 2 jenis, yaitu USB dan Serial. Masing-masing memiliki kelebihan dan kelemahan. Untuk modem wavecom degan port USB memiliki kelebihan yaitu karena modem wavecom dengan port USB dapat digunakan dalam jumlah banyak pada 1 server hanya menggunakan USB hub. Kelemahan modem wavecom dengan port USB ini kurang stabil dan bergantung pada PC untuk masalah catu dayanya sehingga memberatkan kinerja catu daya PC. Untuk modem wavecom dengan port serial memiliki kelebihan memiliki catu daya sendiri menggunakan adaptor sehingga catu daya lebih stabil, akan tetapi untuk penggunaan dalam jumlah banyak harus menggunakan perangkat PCI to Serial yang jumlahnya juga terbatas [12].

\section{METODE PENELITIAN}

Berikut metode yang digunakan pada penelitian 
ini, yaitu meliputi perancangan sistem secara keseluruhan.

\section{A. Blok Diagram Sistem}

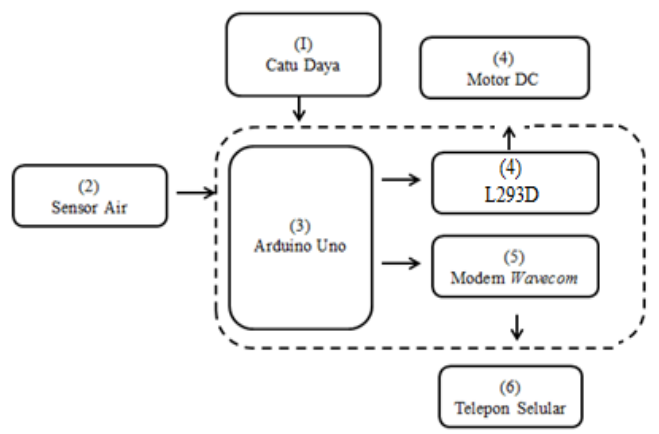

Gbr. 8 Blok Diagram Sistem

Diagram blok pada perancangan alat deteksi turun hujan ini terdiri dari empat bagian yaitu, power supply sebagai sumber tegangan utama disesuaikan kebutuhan sistem, pada bagian kedua Arduino UNO R3 sebagai mikropengendali sistem kerja ini, pada bagian input dari arduino yang terdiri dari sensor deteksi turun hujan dan pada bagian output terdiri dari IC L293D yang digunakan sebagai driver motor kemudian motor DC untuk membuka dan menutup atap buatan dan terakhir bagian modem wavecom yang bekrja untuk mengirimkan sms pemberitahuan ke telepon seluler penerima.

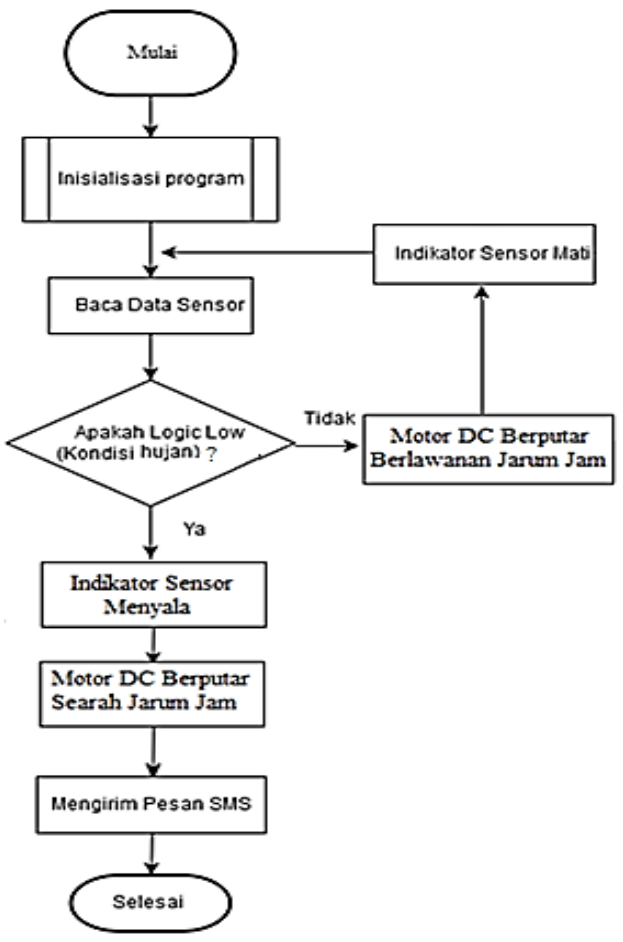

Gbr 9.Flow chat Program Cara Kerja Alat
Berikut keterangan flowchart program cara kerja alat :

1. Mulai : Memulai Program

2. Inisialisasi Program : yang bermaksud untuk menentukan pin input atau output yang akan digunakan dalam merancang alat.

3. Baca data dari sensor deteksi air hujan.

4. Konfirmasi logic high atau low dari deteksi air hujan. Jika logic high (mendeteksi) indikator sensor menyala. Jika logic (tidak mendeteksi) maka motor dc berputar berlawanan jarum jam.

5. Setelah sensor mendeteksi air hujan motor dc berputar searah jarum jam.

6. Kirim notifikasi pesan sms ke handphone pengguna.

\section{IV.HASIL PENELITIAN}

Hasil yang digunakan pada penelitian ini meliputi pengujian catu daya, pengujian sensor deteksi air hujan, pengujian rangkaian komparator, pengujian rangkaian IC L293D, Pengujian Tegangan Catu Daya Modem Wavecom, Pengujian Tegangan Arduino Uno ke IC Max 232 dan pengujian secara keseluruhan.

\section{Pengujian Catu Daya}

Pengujian catu daya dilakukan untuk mengetahui nilai tegangan keluaran dari catu daya tersebut. Rangkaian untuk pengukuran catu daya pada sistem pemantau lampu penerangan jalan ini seperti pada Gambar 10 .

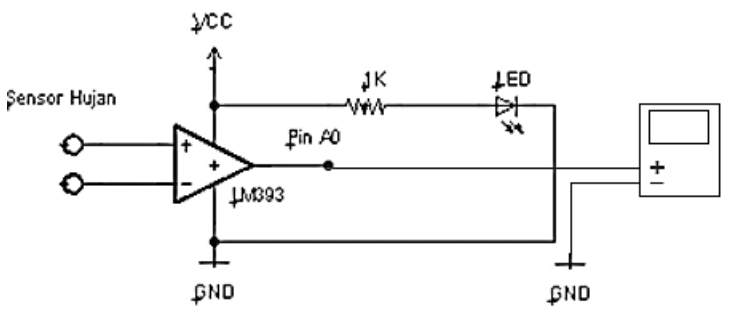

Gbr 10. Pengujian rangkaian catudaya.

Tabel 1 Pengukuran Tegangan Catu Daya

\begin{tabular}{|c|c|c|c|c|}
\hline Parameter & $\begin{array}{c}\text { Datasheet } \\
\text { Regulator } \\
\text { (a) }\end{array}$ & $\begin{array}{c}\text { Hasil } \\
\text { Pengukuran } \\
\text { (b) }\end{array}$ & $\begin{array}{c}\text { Error } \\
(\mathrm{a}-\mathrm{b})\end{array}$ & $\begin{array}{c}\text { Persentase Error (\%) } \\
C=\frac{\mathrm{a}-\mathrm{b}}{a} \times 100 \%\end{array}$ \\
\hline Vout & $\mathbf{1 2}$ Volt & $\mathbf{1 1 , 8 9}$ Volt & $\mathbf{0 , 1 1}$ & $\mathbf{0 , 9 1 \%}$ \\
\hline
\end{tabular}


Pada tabel 1. dapat dijelaskan bahwa terdapat dua hasil pengujian tegangan pada tiap bagian catu daya yaitu pengujian tegangan sekunder trafo, dan pengujian hasil akhir atau output yang dimana perubahan terjadi setelah melewat IC regulator 7012. Pada catu daya persentase error $0,91 \%$ masih bisa berfungsi untuk digunakan.

\section{Pengujian Rangkaian Komparator sebagai sensor hujan}

Pengujian rangkaian komparator ini bertujuan untuk mengetahui tegangan keluaran pada rangkaian komparator ketika ada hujan maupun tidak ada. Rangkaian untuk pengukuran rangkaian komparator deteksi turun hujan ini seperti pada gambar Gambar 11.

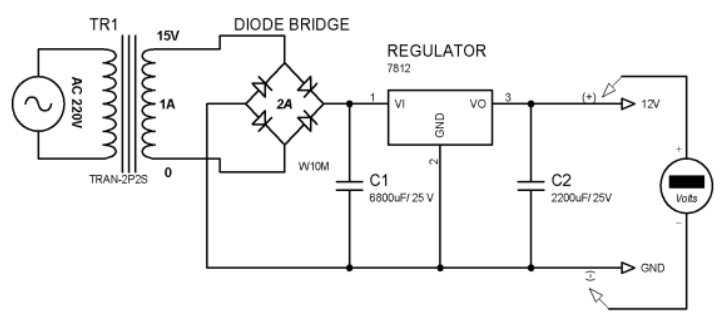

Gbr 11. Rangkaian komparator sebagai sensor air hujan.

Tabel 2 Hasil Pengujian Konversi ADC Terhadap

Tegangan Pada Rangkaian Komparator.

\begin{tabular}{|c|c|c|}
\hline $\begin{array}{c}\text { Kondisi } \\
\text { (Parameter) }\end{array}$ & $\begin{array}{c}\text { Nilai } \\
\text { Tegangan }\end{array}$ & $\begin{array}{c}\text { Nilai ADC } \\
(A D C= \\
\left.\frac{\text { Vin }}{\text { VREF }} \times \text { BIT }\right) \\
(\mathrm{n})\end{array}$ \\
\hline Tidak Hujan & 4.5 Volt & 922 biner \\
\hline Hujan & 1.46 Volt & 300 biner \\
\hline
\end{tabular}

Hasil pengukuran sensor deteksi hujan tersebut menggunakan fitur dari arduino yang sudah tersedia di pin analog dengan mengkonversikan hasil ADC yang dideteksi untuk mengetahui nilai tegangan dari sensor tersebut dengan menggunakan serial monitor sebagai penampil hasil pengukuran. Nilai ADC dan tegangan dari sensor tersebut, ketika tidak hujan 923 biner sedangkan ketika hujan 300 biner.

\section{Pengujian Rangkaian L293D}

Rangkaian driver motor L293D digunakan untuk mengendalikan gerak dari motor DC yang dipasang untuk menggerakan atap buatan berputar searah jarum jam dan berlawanan arah jarum jam dengan memasukan logic ' 1 ' dan ' 0 ' pada pin input L293D.

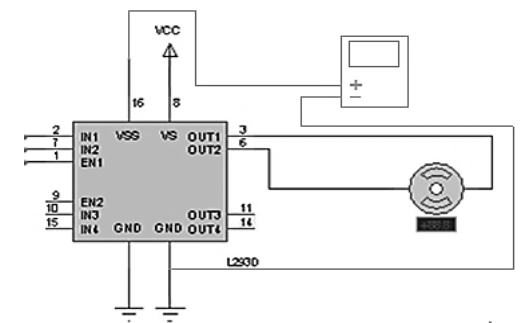

Gbr 12. Rangkaian driver L293D

Tabel 3 Hasil Pengukuran Tegangan keluaran pada driver motor L293D

\begin{tabular}{|c|c|}
\hline Kondisi & $\begin{array}{c}\text { Nilai } \\
\text { Tegangan }\end{array}$ \\
\hline $\begin{array}{c}\text { Tidak } \\
\text { Hujan }\end{array}$ & 8.48 volt \\
\hline Hujan & -8.48 volt \\
\hline
\end{tabular}

\section{Pengujian Tegangan Catu Daya Modem Wavecom}

Dalam pengujian tegangan pada modem wavecom ini bertujuan untuk mengetahui nilai tegangan yang masuk pada modem

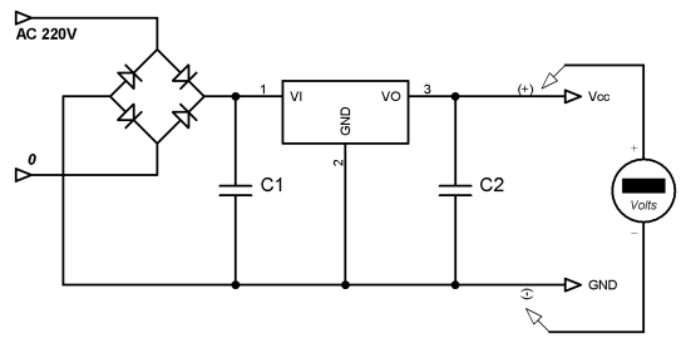

tersebut.

Gbr.13 Rangkaian Tegangan Catu Daya Modem Wavecom

Tabel 4 Hasil Pengukuran Tegangan Vout Adaptor Modem

\begin{tabular}{|c|c|c|c|c|}
\hline Parameter & $\begin{array}{c}\text { Tegangan } \\
\text { Adaptor } \\
\text { (a) }\end{array}$ & $\begin{array}{c}\text { Hasil } \\
\text { Pengukuran } \\
\text { (b) }\end{array}$ & $\begin{array}{c}\text { Error } \\
(\mathrm{a}-\mathrm{b})\end{array}$ & $\begin{array}{c}\text { Persentase Error (\%) } \\
C=\frac{\mathrm{a}-\mathrm{b}}{a} \times 100 \%\end{array}$ \\
\hline
\end{tabular}


Dari hasil pengukuran pada tabel 4 didapatkan nilai tegangan Vout dari adaptor sebesar 7,7 V. Dari datasheet modem wavecom diketahui bahwa modem tersebut menggunakan catu daya eksternal tegangan DC dengan rentang dari 5,5 sampai $32 \mathrm{~V}$ sehingga hasil pengukuran yang didapatkan dari pengukuran tersebut nilai tegangan yang didapatkan bisa digunakan untuk mencatu pada modem wavecom.

\section{Pengujian Tegangan Arduino Uno ke IC MAX 232}

Pengujian Tegangan Arduino Uno ke IC MAX 232 bertujuan untuk mengetahui rangkaian driver IC max 232 yang terpasang dapat berfungsi dengan baik, sehingga komunikasi antara mikro pengendali arduino uno dengan modem wavecom dapat berjalan dengan baik. IC max 232 digunakan sebagai media perantara untuk pengiriman SMS dari modem ke handphone. Pengukuran tegangan max 232 dilakukan dengan tujuan untuk mengetahui perbandingan dari nilai tegangan yang masuk pada max 232 dengan datasheet dari max 232. Adapun rangkaian pengujian tegangan masukan pada max 232 seperti terlihat pada gambar

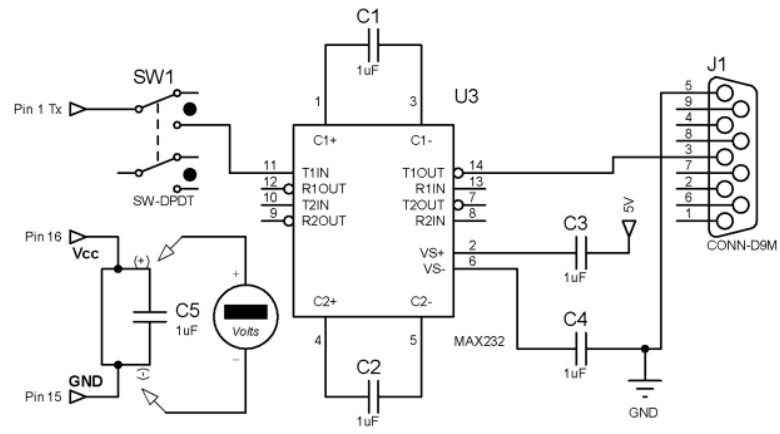

Gbr 14. Rangkaian Pengujian Tegangan Masukan IC MAX 232.

Tabel 4 Hasil Pengukuran Tegangan IC Max 232

\begin{tabular}{|c|c|c|c|c|}
\hline Parameter & $\begin{array}{c}\text { Datasheet } \\
\text { IC MAX } \\
232\end{array}$ & $\begin{array}{c}\text { Rekomendasi } \\
\text { Tegangan } \\
\text { (Datasheet) } \\
\text { (a) }\end{array}$ & $\begin{array}{c}\text { Hasil } \\
\text { Pengukuran } \\
\text { (b) }\end{array}$ & $\begin{array}{c}\text { Persentase } \\
\text { Error (\%) } \\
C \\
\mathrm{a}-\mathrm{b} \\
\mathrm{a}\end{array}$ \\
\hline Vcc & $\begin{array}{c}4,5-5,5 \\
\text { Volt }\end{array}$ & 5 Volt & 5,0 Volt & $0,0 \%$ \\
\hline
\end{tabular}

Dari hasil pengukuran tegangan Max 232 pada tabel 4 diperoleh nilai tegangan sebesar 5,08 V. Nilai tegangan tersebut menunjukan tegangan masih dalam batas aman untuk mencatu max 232 dengan tegangan yang dianjurkan dari datasheet dalam batas normal, karena rentang tegangan yang diperbolehkan untuk mencatu max 232 minimal 4,5 V dan maksimal tegangan mencapai 5,5 V sehingga tegangan tersebut masih dalam batas aman untuk mencatu max 232 tersebut. Proses selanjutnya yaitu pengukuran tegangan konversi dari tegangan transistor-transistor logic (TTL) arduino ke max 232 menjadi tegangan RS232 dilakukan dengan tujuan untuk mengetahui nilai dari tegangan saat logic high dan low yang masuk pada max 232 dan nilai konversi ke RS232.

\subsection{Pengujian Sistem Keseluruhan}

Pengujian sistem secara keseluruhan bertujuan untuk mengetahui keberhasilan dari sistem deteksi air hujan berbasis sms dapat berjalan dengan baik atau tidak. Pengujian keseuruhan sistem dilakukan dengan menggabungkan perintah yang diprogram dalam sistem tersebut. Dalam pengujian sistem secara keseluruhan alat dapat dikatakan baik ketika sensor air yang digunakan sebagai pemicu berjalannnya sistem dapat berfungsi dengan baik dan akan menjalankan perintah berikutnya.

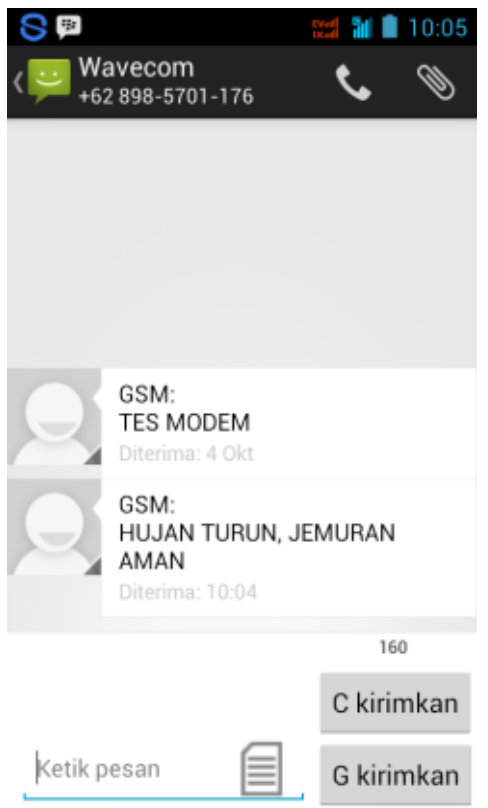

Gbr 15 Tampilan Hasil Pengiriman Pesan Ke Nomor Pengguna 
Tabel 5 Hasil Pengujian Sistem Secara

\begin{tabular}{|c|l|l|l|}
\hline \multicolumn{5}{|c|}{ Keseluruhan } \\
\hline $\begin{array}{c}\text { Langkah } \\
1\end{array}$ & $\begin{array}{l}\text { Sensor Air } \\
\text { yang di amati } \\
\text { hujan }\end{array}$ & $\begin{array}{l}\text { Sistem Aktif } \\
\text { dan Lampu } \\
\text { indikator } \\
\text { menyala }\end{array}$ & Berhasil \\
\hline $\begin{array}{c}\text { Langkah } \\
2\end{array}$ & $\begin{array}{l}\text { Sensor Air } \\
\text { mendeteksi } \\
\text { tidak hujan }\end{array}$ & $\begin{array}{l}\text { Sistem Aktif } \\
\text { dan Lampur } \\
\text { indikator mati }\end{array}$ & Berhasil \\
\hline $\begin{array}{c}\text { Langkah } \\
3\end{array}$ & $\begin{array}{l}\text { Driver motor } \\
\text { L293d }\end{array}$ & $\begin{array}{l}\text { Jemuran mampu } \\
\text { bergerak masuk } \\
\text { ketika hujan dan } \\
\text { bergerak keluar } \\
\text { ketika tidak } \\
\text { hujan }\end{array}$ & Berhasil \\
\hline $\begin{array}{c}\text { Langkah } \\
4\end{array}$ & $\begin{array}{l}\text { Mengirim } \\
\text { pesan SMS ke } \\
\text { Nomor } \\
\text { Pengguna }\end{array}$ & Sistem Berhasil & Berhasil \\
\hline
\end{tabular}

Sistem deteksi air hujan ini dalam pembuatannya dapat mencapai rancangan awal yaitu dapat menjalankan berbagai perintah dalam satu program dan dapat berjalan dengan baik.

\section{KESIMPULAN}

Berikut hasil kesimpulan setelah melakukan pengujian dan analisa pada sistem deteksi suhu ruang server :

1. Perangkat deteksi air hujan dengan report via sms ini dirancang sesuai dengan apa yang diharapkan. Pada perangkat ini sistem yang dibuat berupa mengirimkan sms sebagai pemberitahuan deteksi air hujan turun.

2. Hasil pengukuran tegangan catu daya sebesar sebesar $0,91 \%$. Nilai error tersebut menunjukan bahwa catu daya yang digunakan sudah stabil.

3. Pengujian rangkaian driver motor L293D telah dilakukan. Hasil pengukuran driver motor DC L293D ketika hujan sebesar 8,48 Volt. Sebaliknya pada kondisi tidak hujan 8,48 Volt. 1

4. Hasil pengiriman pesan sebagai notifikasi kondisi hujan, tidak hujan dan jemuran pakaian aman sudah berhasil terkirim ke nomor pengguna.

\section{REFERENSI}

[1] J. Arifin and E. Wahyudi, Eka, Agus Riyanto, "Rancang Bangun Model Sistem Pengendali Dan Pengaman Pintu Berbasis Mikrokontroler AT89S51 Dengan Menggunakan Media Kartu Identifikasi dan Handphone.pdf."

[2] R. Detection and R. T. Sensor, "Implementasi Sistem Monitoring Deteksi Hujan dan Suhu Berbasis Sensor Secara Real Time," Ilm. Semesta Tek., vol. 20, no. 1, pp. 2028, 2017.

[3] M. H. Widianto, "Pengaplikasian Sensor Hujan dan LDR untuk Lampu Mobil Otomatis Berbasis Arduino Uno," Resist. (elektronika Kendali Telekomun. tenaga List. komputer), vol. 1, no. 2, pp. 79-84, 2018.

[4] T. Kobandaha, H. I. R. Mosey, and V. A. Suoth, "Sistem Kontrol Atap Otomatis Tempat Penjemuran Berbasis Mikrokontroler Arduino UNO dan Node Sensor," J. MIPA UNSRAT, vol. 7, no. 2, pp. 42-46, 2018.

[5] A. S.I.R, "Perancangan dan pembuatan alat deteksi turun hujan dengan pemberitahuan melalui sms berbasis mikrokontroler AT89551," Akademi Teknik Telkom Purwokerto, 2012.

[6] F. E. Corporation, "Arduino Uno R3,"

[7] H. Santoso, Panduan Praktis Arduino Untuk Pemula. 2015.

[8] M. B. Agung, Arduino For Beginners, vol. 2, no. 2. 2014.

[9] Onsemi, "Datasheet IC LM393," 2018, pp. $1-10$.

[10] C. Hudaya, "Motor dc," Jakarta: Universitas Indonesia, 2018, pp. 1-25.

[11] T. Instruments, "Datasheet IC L293," 2016.

[12] C. E. Undip, "T. Wavecom," 2004. [Online]. Available: http://saheed.studentsblog.undip.ac.id/files/2010/02/waveco m_M1306B_User_Guide.pdf. 
